\title{
South Atlantic island record reveals a South Atlantic response to the 8.2 kyr event
}

\author{
K. Ljung ${ }^{1}$, S. Björck ${ }^{1}$, H. Renssen ${ }^{2}$, and D. Hammarlund ${ }^{1}$ \\ ${ }^{1}$ Geobiosphere Science Centre, Department of Geology, Quaternary Sciences, Lund University, Sölvegatan 12, 22362 Lund, \\ Sweden \\ ${ }^{2}$ Faculty of Earth and Life Sciences, Vrije Universiteit Amsterdam, De Boelelaan 1085, 1081 HV Amsterdam, The \\ Netherlands
}

Received: 24 April 2007 - Published in Clim. Past Discuss.: 10 May 2007

Revised: 10 December 2007 - Accepted: 21 February 2008 - Published: 29 February 2008

\begin{abstract}
One of the most distinct climate fluctuations during the Holocene is the short and rapid event centred around 8200 years ago, the $8.2 \mathrm{kyr}$ event, which was most likely triggered by glacial melt-water forcing from the receding Laurentide ice-sheet. Evidence for this cooling has primarily been reported from sites around the North Atlantic, but an increasing number of observations imply a more widespread occurrence. Palaeoclimate archives from the Southern Hemisphere have hitherto failed to uncover a distinct climatic anomaly associated with the $8.2 \mathrm{kyr}$ event. Here we present a lake sediment record from Nightingale Island in the central South Atlantic showing enhanced precipitation between 8275 and 8025 cal. yrs BP, most likely as a consequence of increased sea surface temperature (SST). We show that this is consistent with climate model projections of a warming of the South Atlantic in response to reduced north-ward energy transport during the $8.2 \mathrm{kyr}$ event.
\end{abstract}

\section{Introduction}

The cooling associated with the $8.2 \mathrm{kyr}$ event (Alley et al., 1997) is commonly attributed to a weakening of the North Atlantic Deep Water (NADW) formation by rapid discharge of melt-water from ice-dammed lakes to the North Atlantic Ocean from the margin of the Laurentide Ice Sheet (Barber et al., 1999). Evidence for this cooling has primarily been reported from sites around the North Atlantic, but an increasing number of observations imply a more wide-spread occurrence (Alley and Ágústsdóttir, 2005; Wiersma and Renssen,

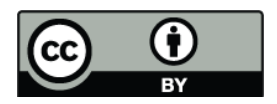

Correspondence to: $\mathrm{K}$. Ljung

(karl.ljung@geol.lu.se)
2006; Rohling and Pälike, 2005). Coupled atmosphereocean model results (Renssen et al., 2001, 2002; Bauer et al., 2004; LeGrande et al., 2006) indicate that such freshening of the North Atlantic caused a significant decrease in the north-ward heat transport, leading to heat retention and associated increases in SST and precipitation in the South Atlantic in response to the weakened thermohaline circulation (THC). Therefore this is a key region for investigating the climatic signature and extent of the $8.2 \mathrm{kyr}$ event, for testing the climate models, and for exploring a potential Holocene anti-phase behavior of north and south (Crowley, 1992; Stocker et al., 1992), equivalent to the so-called bipolar seesaw effect of the last glacial (Broecker, 1998; Stocker, 1998). Although a relationship between seesawing and icerafting (IRD episodes) in the North Atlantic has been hypothesized, no records with a clear anti-phase response to the $8.2 \mathrm{kyr}$ event, or other IRD episodes, have been found (Morrill and Jacobsen, 2005; Broecker, 1998). Marine records from the South Atlantic (Piotrowski et al., 2004) and Tropical Atlantic (Arz et al., 2001) imply a weakening of NADW formation around $8000 \mathrm{cal}$. yrs BP, without a seesaw effect, while other South Atlantic records show no changes during this time (Nielsen et al., 2004).

The Tristan da Cunha island group is located at $37^{\circ} \mathrm{S}$ in the central South Atlantic (Fig. 1a and b), in the path of the westerlies at the northern limit of the West Wind Drift (Höflich, 1984), and has a climate sensitive to atmospheric and oceanographic changes. Mean annual temperature is $14^{\circ} \mathrm{C}$ and annual precipitation close to sea level at The Settlement is ca. $1500 \mathrm{~mm}$ (Höflich, 1984), while values three times higher have been indicated for the more elevated parts of the island. Abundant peat and lake deposits on the islands provide targets for studies of past hydrological changes (Ljung et al., 2006).

Published by Copernicus Publications on behalf of the European Geosciences Union. 

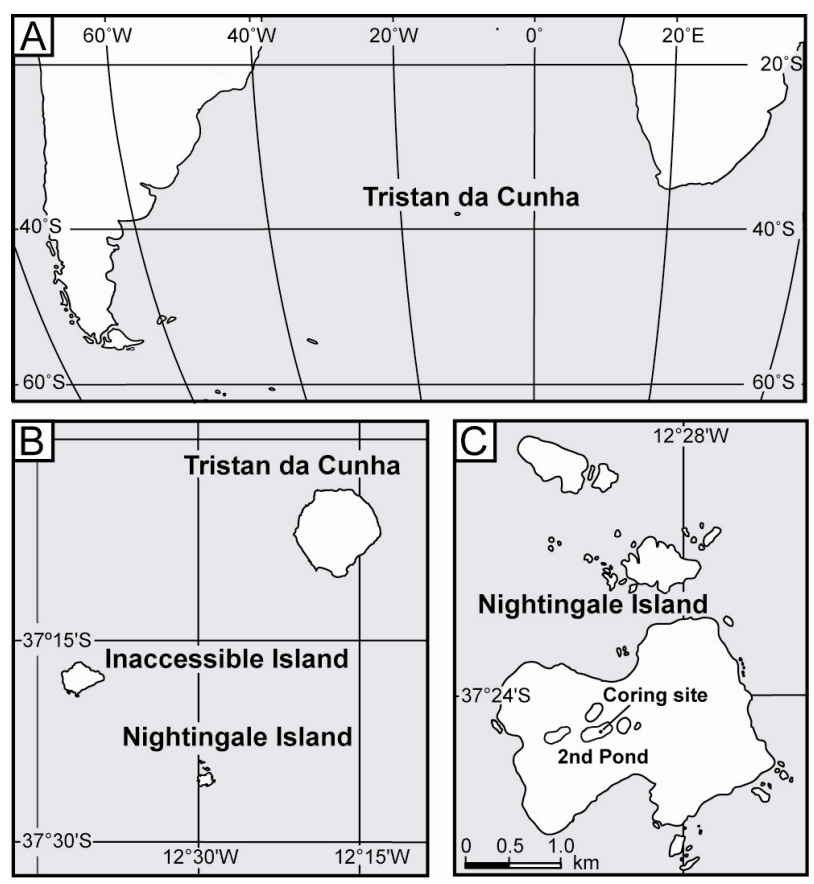

Fig. 1. (A) The position of the Tristan da Cunha island group in the South Atlantic. (B) The three main islands of the group. (C) Nightingale Island and the position of the coring site, 2nd Pond.

We retrieved a $9.6 \mathrm{~m}$ long sediment sequence from the central part of an overgrown lake on the small $\left(3.2 \mathrm{~km}^{2}\right)$ Nightingale Island (Fig. 1c, Fig. 2). This fen, situated at ca. $180 \mathrm{~m}$ above sea level, is called 2nd Pond and has a size of ca. 1 ha. It is a distinct basin with no in- or outlets. Scirpus sp. and Sphagnum sp. dominate the fen vegetation, while thick tussock-grass dominated by Spartina arundinaceae and Poa flabellata cover most of the island. Trees (Phylica arborea), tree ferns (Blechnum palmiforme) and associated shade-tolerant species (Nertera sp., Polypodiaceae) are restricted to slopes and higher areas.

Here we present a palaeoclimatic reconstruction based on a multi-proxy study, including magnetic susceptibility, pollen analysis, and determination of total carbon (TC), nitrogen (TN) and sulphur (TS) content, of the lower part of this sequence, which covers the time period 10700 to 7000 cal. yrs BP (Figs. 2 and 3). The emphasis is on the time around the $8.2 \mathrm{kyr}$ event and any coupling between the South and North Atlantic. We compare our results with a simulation of the $8.2 \mathrm{kyr}$ BP event performed with a coupled atmosphere-ocean climate model.

\section{Methods}

\subsection{Coring, lithological descriptions and correlations}

The sediment sequence was recovered with a $5 \mathrm{~cm}$ Russian chamber corer. All cores were visually described in the field and in detail in the laboratory. Special attention was paid to any signs of potential volcanic ash layers (tephras). Correlations between overlapping cores were carried out visually and with the aid of magnetic susceptibility measurements.

\subsection{Radiocarbon dating}

The chronology is based on ${ }^{14} \mathrm{C}$ measurements performed at the Compact Carbon AMS laboratory in Poznan, Poland, and the Single Stage AMS laboratory in Lund, Sweden. The measurements were obtained on macroscopic plant remains and bulk sediment samples. Radiocarbon ages were converted to calibrated ages using the program OxCal v3.10 (Bronk Ramsey, 2001, 1995) and the SHCal04 calibration data-set (McCormac et al., 2004). The age model was constructed by visual line-fitting through the calibrated radiocarbon dates, and adjusting sedimentation rate changes according to the lithology and lithological changes displayed in the sequence.

\subsection{Total carbon, nitrogen and sulphur measurements}

Total carbon, nitrogen and sulphur content data were obtained on dried and homogenized samples using a Costech Instruments ECS 4010 elemental analyzer. Measurement accuracy is better than $\pm 5 \%$ of the reported values based on replicated standard samples. $\mathrm{C} / \mathrm{N}$ atomic ratios were obtained by multiplying by 1.67 (Bengtsson and Enell, 1986).

If no inorganic carbon, i.e carbonates, are present, TC and $\mathrm{TN}$ contents are directly related to organic matter content, and the $\mathrm{C} / \mathrm{N}$ ratio can be used to asses relative changes in terrestrial versus aquatic organic matter in the sediments (Meyers and Teranes, 2001).

\subsection{Magnetic susceptibility measurements}

Magnetic susceptibility was measured at $4 \mathrm{~mm}$ increments using a Bartington Instruments MS2EI magnetic susceptibility high-resolution surface scanning sensor coupled to a TAMISCAN automatic logging conveyor. In a volcanic environment like this, magnetic susceptibility reflects the minerogenic content of the sediments and provides a proxy for inwash from the catchment (Thompson and Oldfield, 1986).

\subsection{Pollen analysis}

Pollen samples of ca. $1 \mathrm{~cm}^{3}$ were processed following standard method A (Berglund and Ralska-Jasiewiczowa, 1986), with added Lycopodium spores. The counting was made under a light microscope at magnifications of $\times 400$ and $\times 1000$. 


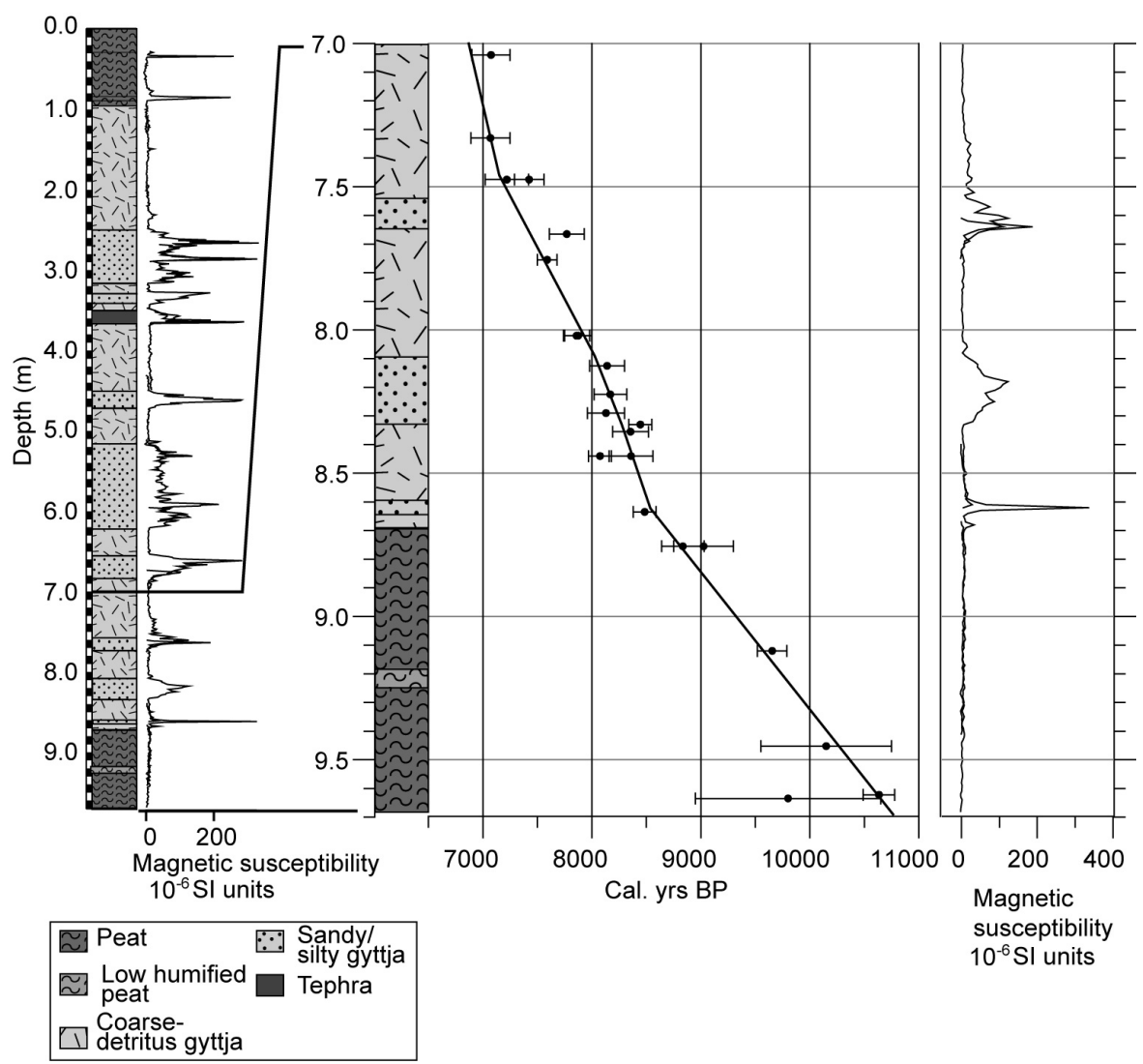

Fig. 2. Graph of lithology and susceptibility of the full 2nd Pond sediment sequence (to the left), with lithology, radiocarbon dates and magnetic susceptibility of the lowermost $2.68 \mathrm{~m}$ to the right. The assumed age-depth relationship is shown by the line through most of the dates and horizontal error bars denote the double standard deviation. Calendar ages are related to AD 1950.

Pollen grains were identified by the help of published photos (Hafsten, 1960), standard pollen keys (Moore et al., 1991), and a small collection of type slides prepared by U. Hafsten and borrowed from the Botanical Museum in Bergen, Norway. The zonation of the pollen diagram is based on the variation of the major taxa and follows the result from the principal component analysis.

\subsection{Principal component analysis}

Principal component analysis (PCA) was performed in MAT$\mathrm{LAB}$ using the function princomp. Undetermined pollen grains were excluded from the analysis. The percentage data were normalized and standardized prior to analysis. PCA was used to extract the major variation from the pollen frequency dataset.

\subsection{Climate model and experimental design}

We performed the simulation of the $8.2 \mathrm{kyr}$ event with version 2 of the ECBilt-CLIO coupled atmosphere-ocean model. The atmospheric component is ECBilt, an atmospheric model (T21 horizontal resolution, three layers) based on quasi-geostrophic equations (Opsteegh et al., 1998). As an extension to the quasi-geostrophic equations, an estimate of the neglected terms in the vorticity and thermodynamic equations is included as a temporally and spatially varying forcing. This forcing is calculated from the diagnostically derived vertical motion field and leads to a considerable improvement of the simulation of the Hadley Cell circulation, resulting in a better representation of the strength and position of the jet stream and transient eddy activity. ECBilt resolves synoptic variability associated with weather patterns. ECBilt is coupled to CLIO, an oceanic general circulation model $\left(3^{\circ} \times 3^{\circ}\right.$ latitude-longitude horizontal resolution, 19 layers in the vertical) coupled to a comprehensive dynamicthermodynamic sea-ice model (Goosse and Fichefet, 1999). The ECBilt-CLIO model reproduces the modern climate (Goosse et al., 2001; Renssen et al., 2002) reasonably well.

The simulation experiment on the $8.2 \mathrm{kyr}$ event was designed as follows. First, starting from a modern quasiequilibrium state, the model was run for 550 years with forcings for $8.5 \mathrm{kyr}$ BP to obtain an early Holocene climate state (Renssen et al., 2002). These forcings are orbital parameters (Berger, 1978), greenhouse gas concentrations 


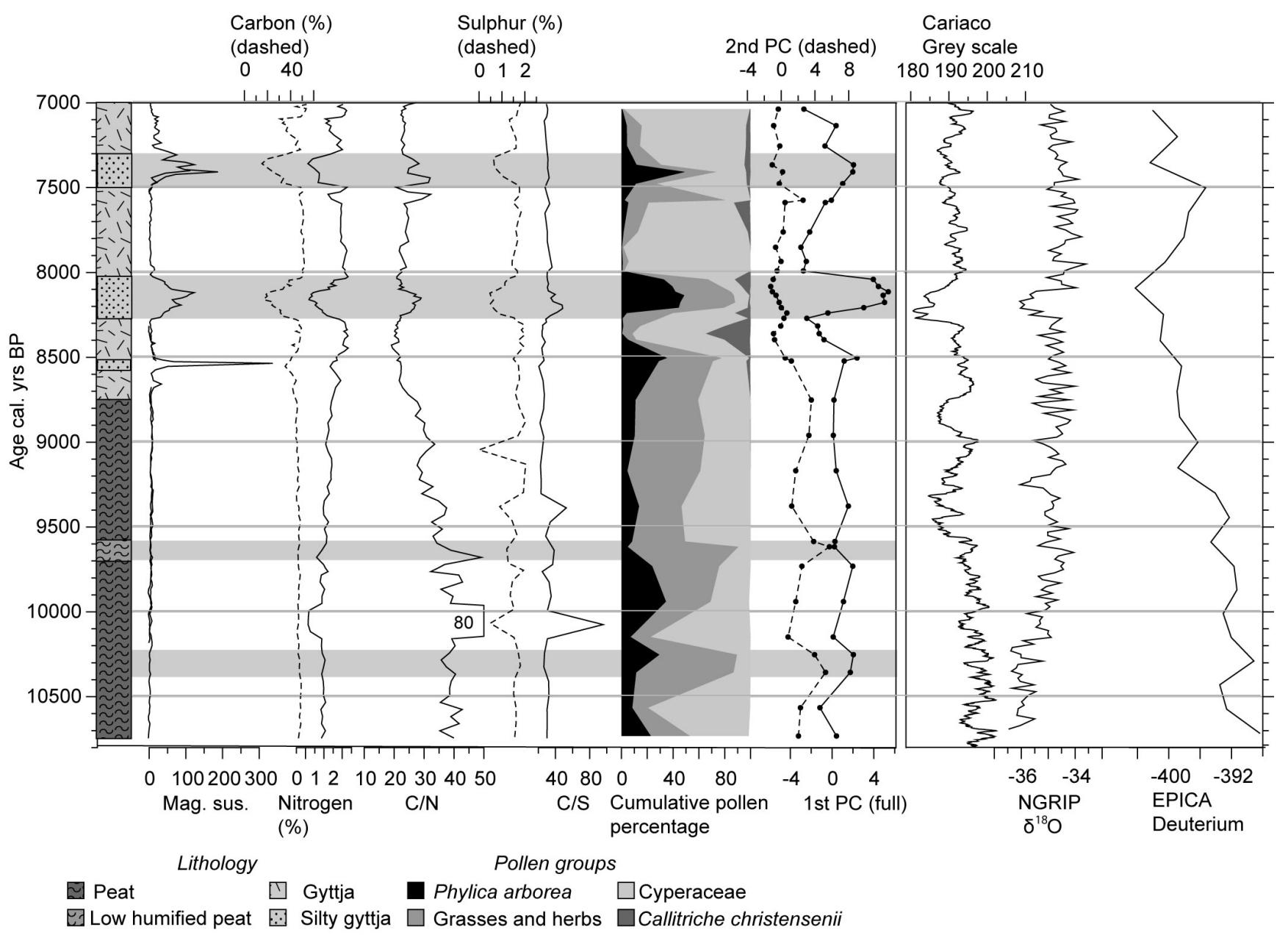

Fig. 3. Graph showing the magnetic susceptibility, content of total carbon (TC) (dashed), total nitrogen (TN), total sulphur content (TS) (dashed), TC/TN ratios, TC/TS ratios, cumulative pollen percentages of Phylica arborea, grasses and herbs, sedges, and Callitriche christensenii, and the values of the first two PCA axes of the pollen dataset accounting for $42 \%$ of the total variance. All data are related to the age model shown in Fig. 2. The $8.2 \mathrm{kyr}$ event and the other events discussed in the text are shown by grey shading. In addition to the 2 nd Pond data, the updated grayscale record from the Cariaco Basin (Haug et al., 2001), the $\delta^{18}$ O record from the NGRIP ice core (Rasmussen et al., 2006), and the deuterium record, averaged over $3.85 \mathrm{~m}$-sections, from the EPICA ice core (Epica Community Members, 2004) are shown. The latter three have independent chronologies based on varve years and ice years BP.

(Raynaud et al., 2000), modified surface albedo in northern Africa to account for a "green" Sahara (Adams and Fauré, 1997), and modified surface albedo and surface elevation in North America to represent the remnant Laurentide ice-heet (Peltier, 1994). At the end of the 550 years, the trend in the global ocean temperature was only $-0.007^{\circ} \mathrm{C} /$ century. Second, this $8.5 \mathrm{kyr}$ BP early Holocene quasi-equilibrium state was perturbed by releasing a freshwater pulse in the Labrador Sea that represents the catastrophic drainage from Lakes Agassiz and Ojibway and the collapse of the Laurentide ice-sheet dome over Hudson Bay. Different freshwater volumes and release rates were tested (Renssen et al., 2002). After the introduction of the freshwater perturbations, the experiments were continued for at least 500 years. Here we present results from one particular experiment that produced a climate anomaly that was closest to what is suggested by proxy data on the $8.2 \mathrm{kyr}$ event, both in terms of magnitude and duration (Renssen et al., 2002; Wiersma and Renssen, 2006). In this experiment, we released a constant freshwater flux of $0.75 \mathrm{~Sv}\left(1 \mathrm{~Sv}=1 \times 10^{6} \mathrm{~m}^{3} / \mathrm{s}\right)$ in the Labrador Sea during 20 years, implying a total volume of $4.67 \times 10^{14} \mathrm{~m}^{3}$. This freshwater volume is close to the highest estimate for the $8.2 \mathrm{kyr}$ event based on geological data (Von Grafenstein et al., 1999). 
Table 1. Radiocarbon dates from the 2nd Pond sequence between 9.635 and $7.04 \mathrm{~m}$ below the fen surface.

\begin{tabular}{crrrl}
\hline Lab. Nr & Depth $(\mathrm{cm})$ & ${ }^{14}$ C Age & Cal. yrs BP $(2 \sigma)$ & Dated material \\
\hline LuS-5799 & 704 & $6220 \pm 50$ & $7075 \pm 175$ & Bulk sediment \\
LuS-6688 & 733 & $6215 \pm 60$ & $7070 \pm 180$ & Terrestrial macrofossils \\
LuS-5812 & 747.5 & $6365 \pm 50$ & $7220 \pm 200$ & Terrestrial macrofossils \\
LuS-5800 & 747.5 & $6560 \pm 50$ & $7425 \pm 135$ & Bulk sediment \\
LuS-6231 & 766.5 & $6950 \pm 60$ & $7770 \pm 160$ & Terrestrial macrofossils \\
LuS-6689 & 775.5 & $6790 \pm 50$ & $7590 \pm 90$ & Terrestrial macrofossils \\
LuS-5813 & 802 & $7105 \pm 50$ & $7860 \pm 120$ & Terrestrial macrofossils \\
LuS-5801 & 802 & $7115 \pm 50$ & $7875 \pm 125$ & Bulk sediment \\
LuS-6230 & 812.5 & $7360 \pm 50$ & $8140 \pm 160$ & Terrestrial macrofossils \\
LuS-6229 & 822.5 & $7410 \pm 50$ & $8170 \pm 150$ & Terrestrial macrofossils \\
LuS-6406 & 829 & $7350 \pm 60$ & $8130 \pm 170$ & Terrestrial macrofossils \\
LuS-6228 & 833 & $7665 \pm 50$ & $8445 \pm 105$ & Terrestrial macrofossils \\
LuS-6407 & 835.5 & $7620 \pm 60$ & $8355 \pm 165$ & Terrestrial macrofossils \\
LuS-5814 & 844 & $7310 \pm 50$ & $8075 \pm 105$ & Terrestrial macrofossils \\
LuS-5802 & 844 & $7605 \pm 100$ & $8360 \pm 200$ & Bulk sediment \\
LuS-6690 & 863.5 & $7725 \pm 50$ & $8485 \pm 105$ & Terrestrial macrofossils \\
LuS-5815 & 875.5 & $8080 \pm 50$ & $8835 \pm 195$ & Terrestrial macrofossils \\
Lus-5803 & 875.5 & $8185 \pm 60$ & $9025 \pm 275$ & Bulk sediment \\
Poz-4444 & 912 & $8720 \pm 50$ & $9655 \pm 135$ & Terrestrial macrofossils \\
Poz-4488 & 945.25 & $9120 \pm 190$ & $10150 \pm 600$ & Terrestrial macrofossils \\
Poz-4941 & 962.25 & $9460 \pm 50$ & $10635 \pm 145$ & Terrestrial macrofossils \\
Poz-4489 & 963.5 & $8760 \pm 310$ & $9800 \pm 850$ & Terrestrial macrofossils \\
\hline & & & &
\end{tabular}

\section{Results}

\subsection{Chronology and climate reconstruction}

The depth-age relationship of the lowermost $2.5 \mathrm{~m}$ was determined by $22{ }^{14} \mathrm{C}$ measurements (Fig. 2, Table 1). The results from this part of the sequence, covering the time period from 10750 to 7000 cal. yrs BP, are presented in Figs. 2 and 3. The temporal resolution of the magnetic susceptibility data is ca. 10 years, equivalent to the geochemical data for the period $8300-7500$ cal. yrs BP. The rest of the geochemical record has a resolution of ca. 20 years, although the pollen record is of lower resolution (30-60 years at 8600-7400 cal. yrs BP and 70-150 years in the oldest part of the sequence).

When constructing the age depth model, breaks in sedimentation rate were assumed to take place at lithological changes, and erroneous ages were considered more likely to be too old than the opposite. Generally bulk sediment samples yielded slightly older ages than macrofossil samples, which indicate that the bulk sediment contains some reworked organic material. We estimate that the uncertainty envelope of the age model is at least \pm 25 years.

The lower part of the sediment sequence consists of fen peat with a variable degree of humification (Fig. 2). The peat is overlain by lacustrine sediments (gyttja) with a low minerogenic content, and this gradual transition at $8.7-8.6 \mathrm{~m}$ is dated to $8800-8600$ cal. yrs BP. The highly organic gyttja is interrupted by distinct units of silty gyttja at $8.33-8.09 \mathrm{~m}$ and at $7.65-7.55 \mathrm{~m}$. In this volcanic bedrock region the minerogenic content of the sediments is mirrored by the magnetic susceptibility values, and closely follows the lithological changes. In the lowermost peat $(9.7-8.7 \mathrm{~m})$ the magnetic susceptibility is very low and remains low after the transition to gyttja. The exception is a temporary susceptibility increase at ca. 8550 cal. yrs BP (Fig. 3), which is likely related to in-wash processes connected to the fen-to-lake transition. Within the two silty gyttja units at $8.33-8.09 \mathrm{~m}$ and 7.65$7.55 \mathrm{~m}$ (Fig. 3), magnetic susceptibility increases markedly. The lower of these units was dated to 8275-8025 cal. yrs BP, making it synchronous with the Northern Hemisphere $8.2 \mathrm{kyr}$ event (Alley et al., 1997). The radiocarbon dates from this unit imply that the sedimentation rate increased, probably as a result of increased deposition of minerogenic and terrestrial organic matter. The upper silty gyttja unit is dated to 7500-7300 cal. yrs BP (Fig. 3).

Total carbon content of the peat and the overlying gyttja ranges from 40 to $45 \%$, which corresponds to at least 80-90\% organic matter due to absence of inorganic carbon (Fig. 3). During the increase in minerogenic matter at 8275 8025 cal. yrs BP, total carbon content drops to $16 \%$, and at $7500-7300$ cal. yrs BP a minimum of $15 \%$ is reached. $\mathrm{TC} / \mathrm{TN}$ ratios of the fen peat generally exceed 40 with a maximum above 80 , which indicates dominance of terrestrial organic matter (Meyers, 2003). TC/TN ratios in the range of 20-30 characterize the lacustrine part of the sequence, with higher values at 8275-8025 and 7500-7300 cal. yrs BP. 


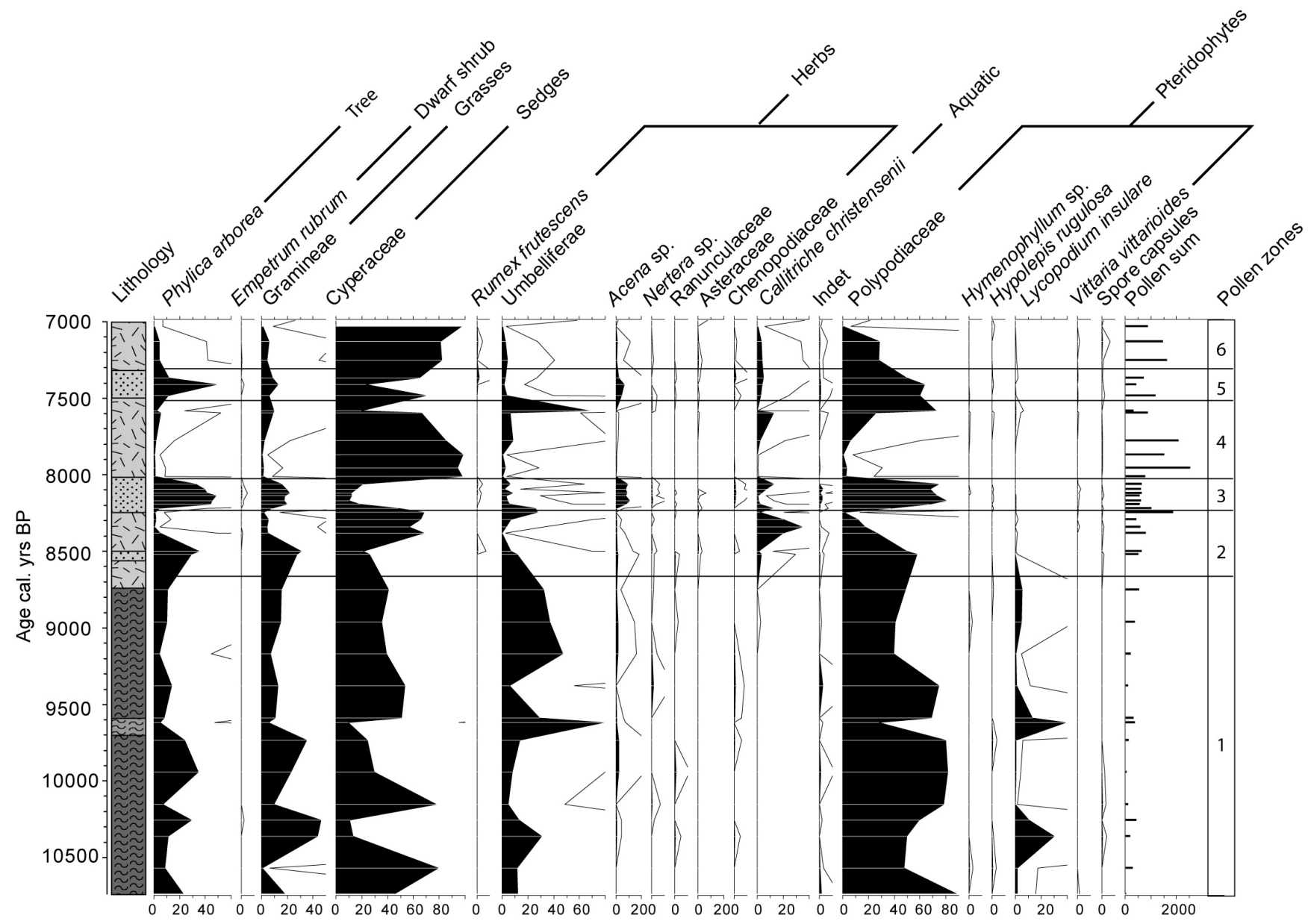

Fig. 4. Graph showing pollen and spore percentage frequencies. Pollen frequencies were calculated in relation to the sum of all pollen types, while Pteridophyte spore frequencies were based on a combined pollen and spore sum. The pollen zonation is based on the major variation in the full pollen percentage dataset which is clearly expressed in the 1st and 2nd PCA axes. The zonation concurs with major lithological changes shown to the left.

The pollen data show large variations which generally follow the lithological changes and variations in the other proxies (Fig. 4). The first two PCA axes explain 33\% and 19\%, respectively of the total variance of the pollen record (Fig. 5). The 1st axis values are primarily determined by Cyperaceae, having the highest scores, and Phylica arborea, Acaena sp., Polypodiaceae, Empetrum rubrum, Gramineae, Chenopodiaceae and Rumex frutescens, which have the lowest (negative) scores. The 2 nd axis values are primarily driven by the high positive scores of Lycopodium insulare and the low negative scores of Callitriche christensenii. These two PCA axes divide the pollen assemblage into different habitat groups: the 1st axis separates local littoral vegetation (Cyperaceae and Callitriche christensenii), dominating pollen zones 2, 4 and 6, from more distal catchment taxa (Phylica arborea, Empetrum rubrum, Acaena sp., Rumex frutescens and Polypodiaceae), dominating pollen zones 3 and 5, whilst the 2nd axis separates the typical wetland species Lycopodium insu- lare, present in pollen zone 1 , from the aquatic species $\mathrm{Cal}$ litriche christensenii, present in pollen zones 2-6. The 1st axis sample scores are closely correlated with TC content $(r=0.8, P<0.001)$, TN content $(r=0.6, P<0.001)$ and magnetic susceptibility $(r=0.8, p<0.001)$.

\subsection{Model results}

In our experiment of the $8.2 \mathrm{kyr}$ event, the THC is significantly weakened by the freshwater perturbation (Renssen et al., 2001, 2002). In the South Atlantic Ocean at $20^{\circ} \mathrm{S}$, the NADW export is reduced by $3 \mathrm{~Sv}$ from $13 \mathrm{~Sv}$ to $10 \mathrm{~Sv}$ during the perturbation, and the northward heat transport decreases by $46 \%$ from 0.28 to $0.15 \mathrm{PW}\left(1 \mathrm{PW}=1 \times 10^{15} \mathrm{~W}\right)$. In the North Atlantic region this leads to strong surface cooling (locally by more than $10^{\circ} \mathrm{C}$ ), which is partly due to positive feedbacks (i.e. ice-albedo and ice-insulation feedbacks) related to the sea-ice expansion. The Arctic sea-ice volume 


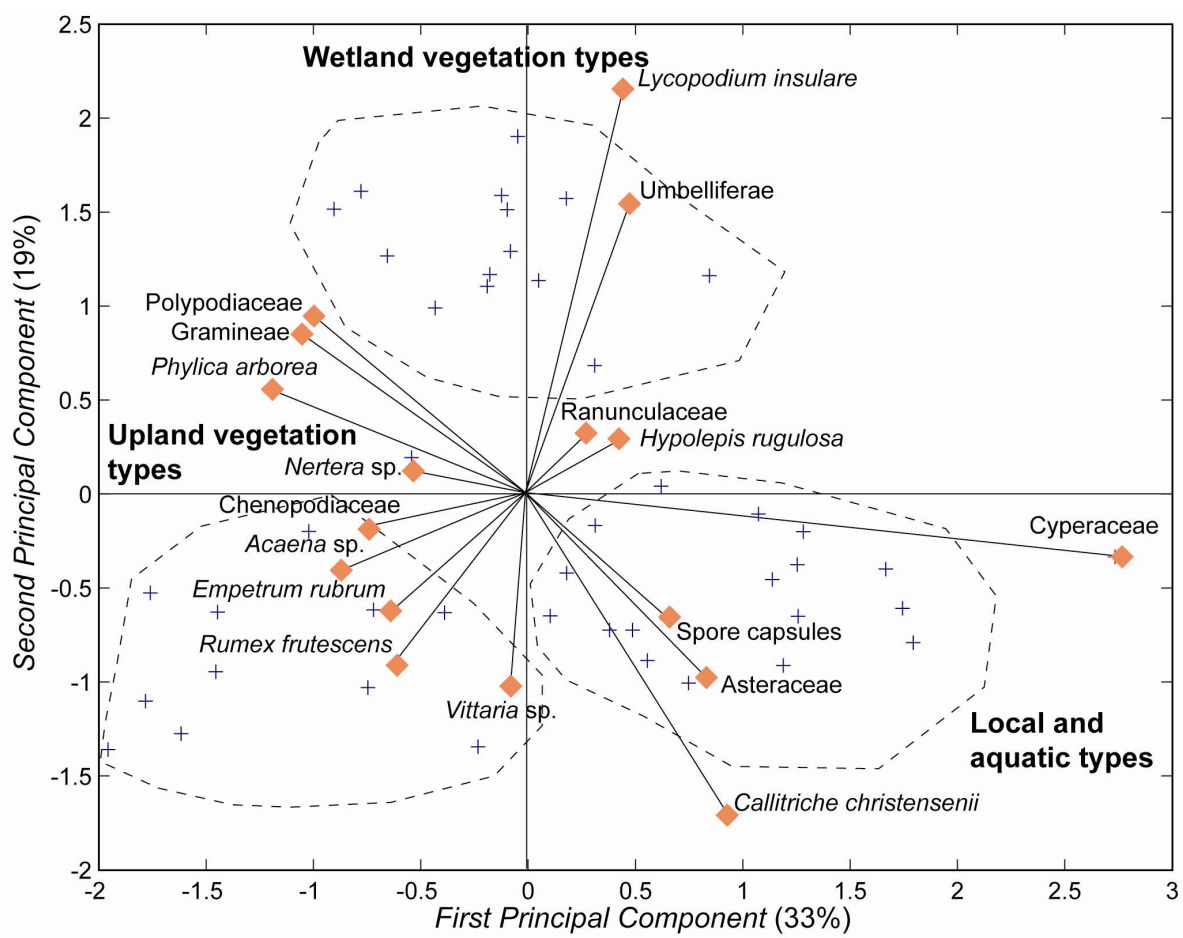

Fig. 5. Biplot of PCA variables (red diamonds), and sample scores (blue crosses). Note that the scores are scaled. Dashed lines indicate the three major sample score groupings. The variable scores show that, the upper central group is influenced by Lycopodium insulare and Umbeliferae, which represent the wetland vegetation assemblages. The two other groups represent the period of gyttja deposition and separate between deposition of pollen from the local vegetation, samples in the lower right corner mainly influenced by Cyperaceae and Callitriche christensenii, and deposition of pollen from more distal parts of the catchment during periods of increased erosion, samples in the lower left corner mainly influenced by Phylica arborea, Polypodiaceae, Acaena sp., Rumex frutescens and Empetrum rubrum.

increases from $16 \times 10^{3} \mathrm{~km}^{3}$ to $23 \times 10^{3} \mathrm{~km}^{3}$ (Renssen et al., 2002).

Over the SE Atlantic Ocean there is a clear increase in relative humidity as a response to the North Atlantic THC weakening, as well as higher surface temperatures and precipitation (Fig. 6). This is especially evident during AugustOctober, which is the period with the largest increases in temperature and precipitation in the model. A similar response to freshwater perturbations was found in the other $8.2 \mathrm{kyr}$ BP experiments discussed in Renssen et al. (2002), demonstrating that the result shown in Fig. 6 is robust in our model. This confirms that in our model the precipitation increases are related to higher SSTs, following the principle: warmer surface ocean, more evaporation, higher air humidity, more precipitation. During the perturbed THC phase (i.e. after year 100 in Fig. 6), the higher levels of SST and precipitation over the SE Atlantic are significantly different (at a 99\% level) from the pre-perturbed state, showing that these increases are not due to natural variability inherent in the model.

It should be noted that, when compared to comprehensive coupled GCMs, our model of intermediate complexity simulates a weak response of the hydrological cycle to a THC weakening. We have chosen to use a model of intermediate complexity for our study of the $8.2 \mathrm{kyr}$ event because this has enabled us to perform a range of multi-centennial runs to test different freshwater scenarios (Renssen et al., 2002). These experiments would not have been feasible with coupled GCMs. As presented in the recent modelintercomparison by Stouffer et al. (2006), coupled GCMs simulate a pronounced southward shift in the ITCZ over the South Atlantic as a response to a THC perturbation, a response that is underestimated in our model. However, the GCM results show that the precipitation increase that is associated with this southward ITCZ shift is restricted to the latitudinal band ranging from 0 to $30^{\circ} \mathrm{S}$, so considerably north of Nightingale Island (at about $37^{\circ} \mathrm{S}$ ). However, the coupled GCMs show a secondary precipitation increase over the South Atlantic between 35 and $40^{\circ} \mathrm{S}$ as a response to the THC weakening. This secondary precipitation maximum is modest (about $+11 \%$ in their $1 \mathrm{~Sv}$ perturbation runs) compared to the primary precipitation maximum associated with the ITCZ shift (up to $+100 \%$ in the $1 \mathrm{~Sv}$ perturbation runs). Stouffer et al. (2006) provide no explanation for this secondary precipitation maximum, but it is noteworthy that in the GCMs the ocean surface also shows considerable warming at this latitude in the South Atlantic, so that it is likely that there is a link between precipitation and SST as is also seen in our model results. Available climate model experiments thus 


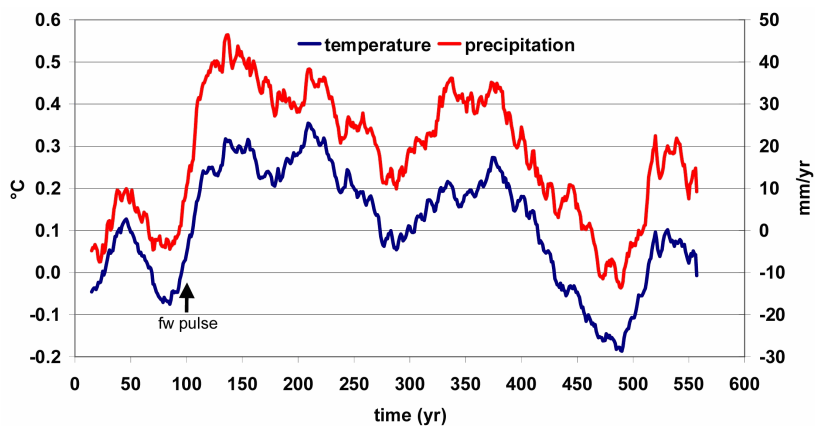

Fig. 6. Simulation of the $8.2 \mathrm{kyr}$ event over the Southeast Atlantic $\left(20^{\circ} \mathrm{W}-10^{\circ} \mathrm{E}, 40^{\circ} \mathrm{S}-20^{\circ} \mathrm{S}\right)$, shown by the response in annual mean sea surface temperature (left axis) and precipitation (right axis) to a freshwater pulse (fw pulse) in the Labrador Sea (Alley and Ágústsdóttir, 2005). Presented are the 30 year running mean anomalies relative to a reference climate in quasi-equilibrium with $8.5 \mathrm{kyr} \mathrm{BP}$ forcings (represented by the first 100 years). In the experiment, the THC of this $8.5 \mathrm{kyr}$ state was perturbed by a 20 year long freshwater flux with a $0.75 \mathrm{~Sv}$ rate in the Labrador Sea, starting at year 100 (Alley and Ágústsdóttir, 2005;Rohling and Pälike, 2005). The THC weakening ends at year 420 , followed by a $\sim 100$ year long "overshoot" during which the accumulated heat is released in the North Atlantic.

support the suggested mechanism: a weakened THC leads to accumulation of heat in the South Atlantic Ocean through the bipolar seesaw mechanism, leading to a warmer surface ocean, increased evaporation, higher air humidity and elevated precipitation levels.

\section{Discussion}

We believe that the pattern in most of our proxy records can be explained in terms of variations in effective humidity and precipitation. The basal peat indicates an at least $9 \mathrm{~m}$ lower water table than at present. The fen-to-lake transition must be the result of significant increase in effective humidity. This implies that a major change of the general circulation pattern took place around $8800 \mathrm{cal}$. yrs BP, likely reflecting the establishment of the present-day circulation regime, due to a meridional shift of the regional fronts. In fact, marine studies in the Atlantic sector of the Southern Ocean (Nielsen et al., 2004) and land-based studies in South America imply that the westerlies intensified after $9000 \mathrm{cal}$. yrs BP (Mayr et al., 2007). Temperature reconstructions from Antarctic ice cores show that the Holocene thermal optimum came to an end at about this time (Epica Community Members, 2004; Masson et al., 2000) (Fig. 3), which resulted in expanded sea ice and a steeper meridional temperature gradient in the Southern Ocean. Model studies have shown that changes in sea-ice extent also causes corresponding changes in the position of the westerlies (Hudson and Hewitson, 2001). Thus, it is likely that the westerlies strengthened and shifted north- wards in the South Atlantic region at the end of the Antarctic thermal optimum around $9000-8500 \mathrm{cal}$. yrs BP, giving rise to increased precipitation on Nightingale Island. The change from peat growth to gyttja deposition and declining wetland species and the appearance of aquatic species in the pollen diagram represented by lower values on the 2nd PCA axis (Fig. 3), are direct effects of this precipitation increase.

At 8275 cal. yrs BP we note enhanced influx of minerogenic and terrestrial organic matter, and increased deposition of pollen types from more remote parts of the catchment. We believe that these simultaneous changes in lithology, minerogenic content, TC/TN ratio and pollen content (Fig. 3) could only have been caused by increased surface run-off in response to increased precipitation. This led to increased catchment erosion and higher input of terrestrial detritus to the basin. This also explains the increase in pollen from taxa favoured by both open ground, such as Rumex frutescens, and closed forest species, such as Phylica arborea. This pollen assemblage change cannot represent a true vegetation change since an expansion of forest would limit open ground taxa and vice versa. Therefore we conclude that the stratigraphic changes at $8275-8025$ cal. yrs BP reflect a period of increased precipitation on Nightingale Island.

At present, stronger westerlies or higher SSTs are the main agents behind enhanced precipitation in the study area. So, which of these possible mechanisms triggered the changes we see? Intensified westerlies are connected to higher wind speeds, resulting in increased concentrations of sea spray, with sea-salt sulphates as an important marine aerosol component in coastal areas. We note the low TS values (Fig. 3) at this time, which can be explained either as an effect of lowered organic content of the sediments or lowered wind transport and deposition of wind-derived sulphur aerosols. Furthermore, the higher TC/TS values show that the relative decline in TS content was larger than that of TC content. This is a strong indication of that the deposition of sea-salt sulphates at Nightingale Island was not higher, but rather lower, during the period $8275-8025$ cal. yrs BP. We therefore hypothesize that the increase in evaporation was caused by higher SST's.

The age of 8275-8025 cal. yrs BP for the inferred precipitation increase at $8.33-8.09 \mathrm{~m}$ is firmly established by the radiocarbon dates and allows for detailed correlation with other climate archives from that period of time. In the light of age error margins of different records, the onset of change is coeval with the onset of the $8.2 \mathrm{kyr}$ event in the new NGRIP ice core, where it is dated to 8260 cal. yrs BP (Rasmussen et al., 2006), as well as with the shift in the Cariaco Basin grey-scale record (Hughen et al., 2000), dated to $8290 \mathrm{cal}$. yrs BP (Fig. 3), and with the inferred decline in North Atlantic meridional overturning circulation (MOC) at $8290 \mathrm{cal}$. yrs BP (Ellison et al., 2006). The inferred increase in precipitation at $8275-8025$ cal. yrs BP is consistent with different model simulations of the $8.2 \mathrm{kyr}$ event (Renssen et al., 2002, 2001; Bauer et al., 2004; LeGrande et al., 2006). Our 
coupled atmosphere-ocean model simulations show statistically significant (at 95\% level) increases in SST (by 0.2 to $0.5^{\circ} \mathrm{C}$ in annual mean) and precipitation (by 10 to $60 \mathrm{~mm} / \mathrm{yr}$ in annual mean) over the South Atlantic as an almost immediate response to a freshwater-induced weakening of the THC (Wiersma and Renssen, 2006) (Fig. 6). This lack of a significant time lag between the Greenland $8.2 \mathrm{ka}$ event and the modeled response in the South Atlantic is, in fact, supported by our dating of the event. In the model, the warming is related to reduced northward heat transport in the Atlantic Ocean, causing heat to accumulate in the South Atlantic, the so-called bipolar seesaw effect, and the warmer surface waters in turn stimulate precipitation in the study region. These model results support our hypothesis that higher SSTs triggered the increased precipitation at our site. Furthermore, the increase in precipitation over Nightingale Island as a response to a warmer ocean was probably stronger than suggested by the model (Fig. 6), as the local topography of the $>300 \mathrm{~m}$ high island causes forced lifting of passing air masses, resulting in distinctly higher precipitation than modeled. The model also shows that the westerlies were not strengthened over the South Atlantic during the $8.2 \mathrm{kyr}$ event. Thus, the increase in precipitation around $8200 \mathrm{cal}$. yrs BP is not only coeval with the $8.2 \mathrm{ka}$ event but also shows the response predicted by our climate model (Fig. 6). We therefore have reason to believe that this change is the South Atlantic expression of the $8.2 \mathrm{ka}$ event. However, our data do not show any indication of a supposed general climate anomaly starting at $8500 \mathrm{cal}$. yrs BP and lasting 500-700 years (Keigwin et al., 2005; Rohling and Pälike, 2005), but only register a more restricted $8.2 \mathrm{kyr}$ event. The duration of the event in our record is approximately 250 years, which is longer than the $160-180$ years of the $8.2 \mathrm{kyr}$ event in the NGRIP (Rasmussen et al., 2006) and Cariaco Basin records (Hughen et al., 2000). The difference is however within the uncertainty of our age model.

The very similar changes in proxy data at $7500-7300 \mathrm{cal}$. yrs BP compared to those at $8275-8025 \mathrm{kyr}$ BP (Fig. 3) indicate that this period was also characterized by increased precipitation. This implies that the period of increased precipitation associated with the $8.2 \mathrm{kyr}$ event was not unique, but part of a pattern of recurring Holocene climatic perturbations (cf. Ljung and Björck, 2007). It is therefore noteworthy that our inferred precipitation increase at 7500-7300 kyr BP coincides with one of the most distinct Holocene North Atlantic IRD peaks $/{ }^{14} \mathrm{C}$ production maxima (Bond et al., 2001). Furthermore, in spite of a different hydrological regime before $8800 \mathrm{cal}$. yrs BP, with peat accumulation preceding lacustrine sedimentation, we note that our pollen data display two peaks in the 2nd axis PCA values (Fig. 3), which are caused by high frequencies of the wetland species Lycopodium insulare. The uppermost of these peaks also coincides with a period of decreased peat humification. Thus, these two periods represent wetter conditions at the peat surface, and are separated by high Phylica arborea and Polypdiaceae frequencies, and high content of Blechnum palmiforme remains, which indicates a drier tree-covered peat surface. The two wetter periods are dated to 10300-10500 and 9600-9700 cal. yrs $\mathrm{BP}$, respectively, and thus coincide with two cold phases in the North Atlantic region (Bond et al., 2001; Björck et al., 2001). We also note that several lithological changes similar to the ones at $8275-8025$ and $7500-7300$ cal. yrs BP occur throughout the rest of the core. This implies that the $8.2 \mathrm{kyr}$ event was not the only period of increased precipitation on Nightingale Island during the Holocene, and it may suggest that changes in the MOC was a recurring phenomenon throughout the Holocene, as proposed by Ljung and Björck (2007).

Since our data imply that there have been several periods of weaker MOC throughout the Holocene this raises the question of whether the precipitation increase we see around $8200 \mathrm{cal}$. yrs BP is a response to the $8.2 \mathrm{ka}$ event proper or if it is only a coincidence. The pattern differs from that recorded in the Greenland ice cores, where the $8.2 \mathrm{ka}$ event stands out as the most pronounced climatic perturbation during the Holocene. However, North Atlantic marine records show that variations of the MOC were a recurring feature during the Holocene, and not restricted to the $8.2 \mathrm{ka}$ event (e.g. Oppo et al., 2003). This implies that reduced heat transport may have caused several periods of increased SST and precipitation in the South Atlantic, which is also reflected in our dataset. The reason for the pronounced cooling in the North Atlantic region at the $8.2 \mathrm{ka}$ event is the combined effect of massive melt-water discharge and weakening of the ocean circulation. In the South Atlantic, however, only the effect of the weaker circulation is registered. There may also have been more general climatic effects of the $8.2 \mathrm{ka}$ event and its assumed massive fresh-water discharge: the MOC may have been influenced by different processes such as dynamics in the amount of fresh-water and sea-ice/ice bergs, atmospheric circulation variability and also internal oceanic forcing (Debret et al., 2007), although the end product in the South Atlantic was the same as during later perturbations. Another or complementary explanation may be that the $8.2 \mathrm{kyr}$ event was an anomaly with a different triggering mechanism, as compared to most of the other Holocene perturbations, for which solar forcing and related feedbacks have been invoked as major players (Bond et al., 2001).

An alternative hypothesis is to explain the fluctuations in our records by climatic perturbations that were restricted to the South Atlantic Ocean, so without the suggested connection to the North Atlantic through the bipolar seesaw. An unambiguous assessment of this possibility requires additional, equally highly resolved Holocene palaeoclimate records from the region. Although we cannot completely discard this alternative hypothesis, we have two strong arguments in favour of the north-south connection. First, the timing of other similar Holocene climatic perturbations registered in the core is similar to the timing of published phases of weakened THC in the North Atlantic. This has 
been discussed in detail in a separate paper that provides an overview for the entire Holocene record (Ljung and Björck, 2007). Second, the response in our records is consistent with the South Atlantic response in climate model experiments in which the THC is perturbed by the release of a realistic freshwater pulse in the North Atlantic Ocean (as shown in Fig. 6). Thus, the variable NADW formation and strength of the THC whih have been shown for the Holocene, with the weakened THC during the $8.2 \mathrm{kyr}$ event as only one of several similar perturbations (Oppo et al., 2003) is supported by our data.

\section{Conclusions}

Our island paleoclimate record from the central South Atlantic gives evidence of increased precipitation in response to the North Atlantic 8.2 kyr BP cooling. This was most likely caused by increased SSTs in the surrounding ocean, which is also demonstrated by modelling the coupled atmosphereocean response to an $8.2 \mathrm{kyr} \mathrm{BP}$ freshwater pulse into the North Atlantic. This is the first clear demonstration of a climatic response in the South Atlantic to the $8.2 \mathrm{kyr}$ BP event, and our inter-hemispheric correlation implies that the disruption of NADW formation caused by the drainage of the Laurentide ice-dammed lakes affected the MOC of the entire Atlantic Ocean.

Acknowledgements. This study was supported by the Swedish Research Council (VR) through grants to SB's "Atlantis" project (G 5103-20005076/2000). H. Renssen is sponsored by the Netherlands Organization for Scientific Research (N.W.O). We are grateful to the Botanical Museum in Bergen for access to U. Hafsten's pollen type collection from the islands. We thank O. Bennike, J. Glass and M. Green for field work assistance and James and Felicity Glass and several other Tristan islanders for general logistic support.

Edited by: H. Goosse

\section{References}

Adams, J. M. and Fauré, H.: Review and atlas of palaeovegetation: Preliminary land ecosystem maps of the world since the Last Glacial Maximum, Oak Ridge National Laboratory, TN, USA, at: www.esd.ornl.gov/projects/qen, 1997.

Alley, R. B., Mayewski, P. A., Stuiver, M., Taylor, K. C., and Clark, P. U.: Holocene climatic instability: A prominent, widespread event 8200 yr ago, Geology, 25, 483-486, 1997.

Alley, R. B. and Ágústsdóttir, A. M.: The 8k event: Cause and consequences of a major Holocene abrupt climate change, Quat. Sci. Rev., 24, 1123-1149, 2005.

Arz, H. W., Gerhardt, S., Pätzold, J., and Röhl, U.: Millennial-scale changes of surface- and deep-water flow in the western tropical Atlantic linked to northern hemisphere high-latitude climate during the Holocene, Geology, 29, 239-242, 2001.

Barber, D. C., Dyke, A., Hillaire-Marcel, C., Jennings, A. E., Andrews, J. T., Kerwin, M. W., Bilodeau, G., McNeely, R., Southon, J., Morehead, M. D., and Gagnon, J. M.: Forcing of the cold event of 8,200 years ago by catastrophic drainage of Laurentide Lakes, Nature, 400, 344-348, 1999.

Bauer, E., Ganopolski, A., and Montoya, M.: Simulation of the cold climate event 8200 years ago by meltwater outburst from Lake Agassiz, Paleoceanography, 19, PA001030, doi:10.1029/2004PA001030, 2004.

Bengtsson, L. and Enell, M.: Chemical analysis, in: Handbook of Holocene palaeoecology and palaeohydrology., edited by: Berglund, B. E., John Wiley \& Sons Ldt, Chichester, 423-451, 1986.

Berger, A. L.: Long-term variations of daily insolation and quaternary climatic changes, J. Atmos. Sci., 35, 2363-2367, 1978.

Berglund, B. E. and Ralska-Jasiewiczowa, M.: Pollen analysis and pollen diagrams, in: Handbook of Holocene palaeoecology and palaeohydrology, edited by: Berglund, B. E., Wiley, Chichester, 455-484, 1986.

Björck, S., Muscheler, R., Kromer, B., Andresen, C. S., Heinemeier, J., Johnsen, S. J., Conley, D., Koç, N., Spurk, M., and Veski, S.: High-resolution analyses of an Early Holocene climate event may imply decreased solar forcing as an important climate trigger, Geology, 29, 1107-1110, 2001.

Bond, G., Kromer, B., Beer, J., Muscheler, R., Evans, M. N., Showers, W., Hoffman, S., Lotti-Bond, R., Hajdas, I., and Bonani, G.: Persistent solar influence on North Atlantic climate during the Holocene, Science, 294, 2130-2136, 2001.

Broecker, W. S.: Paleocean circulation during the last deglaciation: A bipolar seesaw?, Paleoceanography, 13, 119-121, 1998.

Bronk Ramsey, C.: Radiocarbon calibration and analysis of stratigraphy: The oxcal program, Radiocarbon, 37, 425-430, 1995.

Bronk Ramsey, C.: Development of the radiocarbon program oxcal, Radiocarbon, 43, 381-389, 2001.

Crowley, T. J.: North Atlantic deep water cools the southern hemisphere, Paleoceanography, 7, 489-497, 1992.

Debret, M., Bout-Roumazeilles, V., Grousset, F., Desmet, M., McManus, J. F., Massei, N., Sebag, D., Petit, J.-R., Copard, Y., and Trentesaux, A.: The origin of the 1500-year cycles in the Holocene North-Atlantic records, Clim. Past, 3, 569-575, 2007, http://www.clim-past.net/3/569/2007/.

Ellison, C. R. W., Chapman, M. R., and Hall, I. R.: Surface and deep ocean interactions during the cold climate event 8200 years ago, Science, 312, 1929-1932, 2006.

Epica Community Members: Eight glacial cycles from an Antarctic ice core, Nature, 429, 623-628, 2004.

Goosse, H. and Fichefet, T.: Importance of ice-ocean interactions for the global ocean circulation: A model study, J. Geophys. Res., 104, 23 337-323 355, 1999.

Goosse, H., Selten, F. M., Haarsma, R. J., and Opsteegh, J. D.: Decadal variability in high northern latitudes as simulated by an intermediate-complexity climate model, Ann. Glaciol., 33, 525532, 2001.

Hafsten, U.: Pleistocene development of vegetation and climate in Tristan da Cunha and Gough Island., Årbok Univeristetet $\mathrm{i}$ Bergen, Mat.-Naturv. Serie. A, 20, 1-45, 1960.

Haug, G. H., Hughen, K. A., Peterson, L. C., Sigman, D. M., and Rohl, U.: Southward migration of the intertropical convergence zone through the Holocene, Science, 293, 1304-1308, 2001.

Hudson, D. A. and Hewitson, B. C.: The atmospheric response to a reduction in summer Antarctic sea-ice extent., Clim. Res., 16, 76-99, 2001. 
Hughen, K. A., Southon, J. R., Lehman, S., and Overpeck, J.: Synchronous radiocarbon and climate shifts during the last deglaciation, Science, 290, 1951-1955, 2000.

Höflich, O.: Climate of South Atlantic Ocean., in: World survey of climatology, edited by: van Loon, H., Elsevier, Oxford, 195, 1984.

Keigwin, L. D., Sachs, J. P., Rosenthal, Y., and Boyle, E. A.: The 8200 year B.P. event in the slope water system, western subpolar North Atlantic, Paleoceanography, 20, PA001074, doi:10.1029/2004PA001074, 2005.

LeGrande, A. N., Schmidt, G. A., Shindell, D. T., Field, C. V., Miller, R. L., Koch, D. M., Faluvegi, G., and Hoffman, G.: Consistent simulations of multiple proxy responses to an abrupt climate change event, PNAS, 103, 837-842, 2006.

Ljung, K., Björck, S., Hammarlund, D., and Barnekow, L.: Late Holocene multi-proxy records of environmental change on the South Atlantic island Tristan da Cunha, Palaeogeog., Palaeoclim., Palaeoecol., 241, 539-560, 2006.

Ljung, K. and Björck, S.: Holocene climate and vegetation dynamics on Nightingale Island, South Atlantic - an apparent interglacial bipolar seesaw in action?, Quat. Sci. Rev., 26, 3150-3166 2007.

Masson, V., Vimeux, F., Jouzel, J., Morgan, V., Delmotte, M., Ciais, P., Hammer, C., Johnsen, S., Lipenkov, V. Y., Mosley-Thompson, E., Petit, J.-R., Steig, E. J., Stievenard, M., and Vaikmae, R.: Holocene climate variability in Antarctica based on 11 ice-core isotopic records, Quat. Res., 54, 348-358, 2000.

Mayr, C., Wille, M., Haberzettl, T., Fey, M., Janssen, S., Lücke, A., Ohlendorf, C., Oliva, G., Schäbitz, F., Schleser, G. H., and Zolittschka, B.: Holocene variability of the southern hemisphere westerlies in Argentinean Patagonia (52s), Quat. Sci. Rev., 26, 579-584, doi:10.1016/j.quascirev.2006.11.013, 2007.

McCormac, F. G., Hogg, A. G., Blackwell, P. G., Buck, C. E., Higham, T. F. G., and Reimer, P. J.: Shcal04 southern hemisphere calibration, 0 - 11 kyr cal BP, Radiocarbon, 46, 10871092, 2004.

Meyers, P. A. and Teranes, J. L.: Sediment organic matter, in: Tracking environmental change using lake sediments, edited by: Last, W. M. and Smol, J. P., Kluwer Academic Publishers, Dordrecht, 239-269, 2001.

Meyers, P. A.: Applications of organic geochemistry to paleolimnological reconstructions: A summary of examples from the Laurentian Great Lakes, Org. Geochem., 34, 261-289, 2003.

Moore, P. D., Webb, J. A., and Collinson, M. E.: Pollen analysis, 2nd ed., Blackwell Scientific, Oxford, 216 pp., 1991.

Morrill, C. and Jacobsen, R. M.: How widespread were the climate anomalies 8200 years ago?, Geophys. Res. Lett., 32, L19701, doi:10.1029/2005GL023536, 2005.

Nielsen, S. H. H., Koc, N., and Crosta, X.: Holocene climate in the Atlantic sector of the southern ocean: Controlled by insolation or oceanic circulation?, Geology, 32, 317-320, 2004.
Oppo, D. W., McManus, J. F., and Cullen, J. L.: Deepwater variability in the Holocene epoch, Nature, 422, 277-279, 2003.

Opsteegh, J. D., Haarsma, R. J., Selten, F. M., and Kattenberg, A.: Ecbilt: A dynamic alternative to mixed boundary conditions in ocean models, Tellus, 50A, 348-367, 1998.

Peltier, W. R.: Ice age paleotopography, Science, 265, 195-201, 1994.

Piotrowski, A. M., Goldstein, S. L., Hemming, S. R., and Fairbanks, R. G.: Intensification and variability of ocean thermohaline circulation through the last deglaciation, Earth Planet. Sci. Lett., 225, 205-220, 2004.

Rasmussen, S. O., Andersen, K. K., Svensson, A. M., Steffensen, J. P., Vinther, B. M., Clausen, H. B., Siggaard-Andersen, M.L., Johnsen, S. J., B., L. L., Dahl-Jensen, D., Bigler, M., Röthlisberger, R., Fischer, H., Goto-Azuma, K., Hansson, M. E., and Ruth, U.: A new Greenland ice core chronology for the last glacial termination, J. Geophys. Res., 111, D06102, doi:10.1029/2005JD006079, 2006.

Raynaud, D., Barnola, J.-M., Chappellaz, J., Blunier, T., Indermühle, A., and Stauffer, B.: The ice record of greenhouse gases: A view in the context of future changes, Quat. Sci. Rev., 19, 9-17, 2000.

Renssen, H., Goosse, H., Fichefet, T., and Campin, J.-M.: The 8.2 kyr event simulated by a global atmosphere-sea-ice-ocean model, Geophys. Res. Lett., 28, 1567-1570, 2001.

Renssen, H., Goosse, H., and Fichefet, T.: Modelling the effect of freshwater pulses on the early Holocene climate: The influence of high-frequency climate variability, Paleoceanography, 17, PA000649, doi:10.1029/2001PA000649, 2002.

Rohling, E. J. and Pälike, H.: Centennial-scale climate cooling with a sudden cold event around 8,200 years ago, Nature, 434, 975979, 2005.

Stocker, T. F., Wright, D. G., and Mysak, L. A.: A zonally averaged, coupled ocean-atmosphere model for paleoclimate studies, J. Climate, 5, 773-797, 1992.

Stocker, T. F.: The seesaw effect, Science, 282, 61-62, 1998.

Stouffer, R. J.: Investigating the causes of the response of the thermohaline circulation to past and future climate changes, J. Climate, 19, 1365-1387, 2006.

Thompson, R. and Oldfield, F.: Environmental magnetism, Allen \& Unwin, London, 227 pp., 1986.

Wiersma, A. P. and Renssen, H.: Model-data comparison for the 8.2 ka BP event: Confirmation of a forcing mechanism by catastrophic drainage of Laurentide Lakes, Quat. Sci. Rev., 25, 63-88, 2006.

Von Grafenstein, U., Erlenkeuser, H., Brauer, A., Jouzel, J., and Johnsen, S. J.: A Mid-European decadal isotope-climate record from 15,500 to 5000 years B.P, Science, 284, 1654-1657, 1999. 